Original Articles

\title{
Habitat structure and neighbor linear features influence more carabid functional diversity in olive groves than the farming system
}

\author{
Pedro Martins da Silva ${ }^{a, b, *}$, Joana Oliveira ${ }^{c}$, Alberto Ferreira ${ }^{a}$, Felícia Fonseca ${ }^{c}$, José A. Pereira $^{c}$, \\ Carlos A.S. Aguiar ${ }^{\mathrm{b}}$, Artur R.M. Serrano ${ }^{\mathrm{b}}$, José Paulo Sousa ${ }^{\mathrm{a}}$, Sónia A.P. Santos ${ }^{\mathrm{c}}$ \\ a Centre for Functional Ecology, Department of Life Sciences, University of Coimbra, Calçada Martins de Freitas, 3000-456 Coimbra, Portugal \\ ${ }^{\mathrm{b}}$ Centre for Ecology, Evolution and Environmental Change, Faculty of Sciences, University of Lisbon, Rua Ernesto de Vasconcelos Ed. C2-5 Floor, Campo Grande, 1749- \\ 016 Lisbon, Portugal \\ ${ }^{c}$ Mountain Research Centre, School of Agriculture, Polytechnic Institute of Bragança, 5300-253 Bragança, Portugal
}

\section{A R T I C L E I N F O}

\section{Keywords:}

Functional groups

Ground beetles

Land-use intensity

Landscape configuration

Organic farming

Integrated production

\begin{abstract}
A B S T R A C T
The effects of land-use management and environmental features at different scales on carabid beetle diversity and trait structure were assessed across olive groves in northeastern Portugal. We selected organic and integrated olive groves that were distinct in terms of specific management practices, local linear features and landscape configurations. Besides the management intensification levels, differences in carabid diversity and community traits were mainly due to local habitat and ecological linear structures at a finer spatial scale. Carabid community traits related to disturbance, namely traits of body size and species dispersal ability, responded to land-use intensity and particular olive grove features were influencing diversity patterns. Within the olive grove patches, larger and brachypterous species were associated to plots with more dense vegetation cover while macropterous and small-sized species were more associated to open areas. Also, larger carabid species benefitted from higher patch size heterogeneity within the landscape mosaics. Our findings indicate that the effects of farming system is contingent on the specific management practices, local and linear features present in agroecosystems such as olive groves. Particularly, the influence of local features on carabid diversity patterns and community traits linked to dispersal and movement may be crucial in maintaining pest control at a landscape scale.
\end{abstract}

\section{Introduction}

Land-use changes and agriculture intensification are among the main drivers of species diversity in Western Europe since the end of the Second World War (Puech et al., 2014; Stoate et al., 2009; Woodcock et al., 2005). High pesticide and fertilizer inputs, tillage operations, intensive grazing and the increasing simplification of agricultural landscapes, have shaped biodiversity patterns at local and regional levels (Flohre et al., 2011).

Negative effects of intensification are especially critical for elements of biodiversity supporting key ecosystem functions, such as carabid beetles with regards to the pest control service in agroecosystems (Kotze et al., 2011; Kromp, 1999). However, the effects of management practices may vary across different taxa and functional groups (e.g. Bengtsson et al., 2005; Flohre et al., 2011), depending on particular species traits (e.g. Barbado and van Halder, 2009; Guerrero et al., 2014). Inconsistent results have been found in the literature concerning the beneficial effects of agroecosystems with lower levels of land-use management in relation to conventional agriculture (Ponce et al., 2011; Puech et al., 2014). In fact, several studies have shown that carabid beetles are influenced by agricultural practices, occurring generally in higher abundance or diversity in less intensive land-use systems, such as organic farming (e.g. Döring and Kromp, 2003; Kromp, 1999). Yet, some species may benefit from higher prey availability in highly productive conventionally managed farms (Diekötter et al., 2010; Martins da Silva et al., 2008; Vanbergen et al., 2005).

Other environmental factors, besides management practices or the farming system, may influence community structure of carabid beetles within agroecosystems.

Recent studies have pointed out that microhabitat conditions within agricultural fields and the context of the surrounding landscape may influence carabid communities in agroecosystems (Bengtsson et al., 2005; Cardarelli and Bogliani, 2014; Dauber et al., 2003; Diekötter et al., 2010). For instance, linear structures within the agricultural patches, such as field margins or hedgerows may provide shelter (breeding sites, overwintering habitats, etc.) for several species (Cole

\footnotetext{
* Corresponding author at: Centre for Functional Ecology, Department of Life Sciences, University of Coimbra, Calçada Martins de Freitas, 3000-456, Coimbra, Portugal.

E-mail address: pedrogpmartins@gmail.com (P. Martins da Silva).
} 
et al., 2010; MacLeod et al., 2004; Werling and Gratton, 2008; Woodcock et al., 2005).

Moreover, carabid community structure and functional diversity in agroecosystems may also depend on the levels of heterogeneity and the specific configuration of an agricultural landscape (Barbado and van Halder, 2009; Diekötter et al., 2010; Woltz et al., 2012; Woodcock et al., 2010). For instance, good dispersers or species with a preference for open habitats may be favored by agroecosystems dominated by homogenized open areas (Döring and Kromp, 2003), while more sensitive species with large-sized bodies and/or poorer dispersal ability may undergo a negative impact due to landscape simplification (Cardarelli and Bogliani, 2014; Kotze and O'Hara, 2003; Martins da Silva et al., 2008; Petit and Usher, 1998). Also, a landscape configuration driving dispersal limitation among local communities have been increasingly recognized to play an important role in structuring community composition of carabid beetles at larger spatial scales (Driscoll et al., 2010; Niemelä and Spence, 1994; Ulrich and Zalewski, 2007).

Local and landscape features may be particularly important in complex landscape mosaics, such as the case of the traditionally managed olive grove agroecosystems. In these landscapes functional diversity is crucial for the maintenance of key ecosystem services, such as the pest control (e.g. Santos et al., 2007). For example, carabid beetles play an important role as predators of Bactrocera oleae (Rossi), the major pest of olives in most commercial olive growing regions worldwide (Daane and Johnson, 2010; Dinis et al., 2016). Carabid beetle diversity in olive groves may depend on the direct effects of landuse management, but also on particular features of the landscape mosaic (Fernández-Escobar et al., 2013; Martins da Silva et al., 2011; Romero-Alcaraz and Ávila, 2000). Yet, no attempts have been made to study the relative influence of management intensity and environmental factors at local and landscape levels on carabid beetle communities.

The aim of this study was to assess the effects of environmental factors related to microhabitat conditions and features of the surrounding landscape on carabid beetle diversity and community (trait) structure in olive groves of northeastern Portugal. To accomplish that, we selected organic and integrated olive groves along an intensity gradient of farming practices to investigate which factors (management intensity or local or landscape features) were affecting carabid beetle communities. Our hypothesis is that, despite the importance of the farming system, carabid diversity and community trait will be mainly influenced by specific management practices and particular local and landscape features across the different olive groves.

We predict that carabid response traits related to higher sensitiveness to land-use management (larger sized and poorer dispersers) will benefit from olive grove features supporting refuge habitats: be they provided by the configuration of the surrounding landscape (e.g. contiguous woodland patches) or linear structures (e.g. hedgerows) providing microhabitat conditions at finer spatial scales within the olive grove patches.

\section{Material and methods}

\subsection{Study sites}

The study was conducted in 2011 (in spring and autumn seasons), in nine olive groves in the area surrounding Mirandela municipality, Trásos-Montes region, northeastern Portugal (Fig. 1). The study sites were in average $5 \mathrm{~km}$ apart ( $2 \mathrm{~km}$ minimum, $15 \mathrm{~km}$ maximum), belonging to the same climatic zone (typically Mediterranean, characterized by hot and dry summers and mild and moist winters), and with similar site conditions in terms of altitude (mean altitude of $393 \mathrm{~m}$ ), mean annual rainfall (about $524 \mathrm{~mm}$ ) and temperature (the mean maximum temperature is $22.7^{\circ} \mathrm{C}$ and the mean minimum temperature is $9.6^{\circ} \mathrm{C}$ ). Main characteristics and management data of all olive grove sites were obtained from interviews with farmers after the growing season (Appendix A, Tables A1 and A2 in Supplementary material). Selected olive groves represented a gradient of land-use intensity of the most common farming practices followed by olive growers in the region of Trás-os-Montes. From the nine study sites, four represented organic farming systems and five were olive groves under integrated production (Appendix A, Table A2 in Supplementary material).

\subsection{Sampling of carabid beetles}

Sampling was done in the first week of May (spring) and in the last week of October 2011 (autumn). Although shorter periods of pitfall trapping may miss some carabid species due to the lack of a whole period of carabid beetle activity, it has been argued that for comparative purposes, the number of traps may have more influence on the results than the length of the trapping period (Lövei and Magura, 2011; Niemelä et al., 1990). This may be especially true in relatively homogeneous systems such as the case of olive groves.

At each site, a regular square grid of $4 \times 4$ sampling points was laidout within the center of the olive grove patch. A pitfall trap was set up in each sampling point, totalizing 16 pitfall traps at each study site and thus 144 sampling points across the 9 study sites. Pitfall traps consisted of plastic cups with a top-diameter $115 \mathrm{~mm}$ and $130 \mathrm{~mm}$ height, which were dug into the ground so that the border of the cup was leveled with the soil surface. Pitfall traps were filled with $250 \mathrm{ml}$ of ethylene glycol (anti-freeze liquid); a lid supported by iron wires was placed to exclude rain, debris and small vertebrates. Traps were spaced $45-50 \mathrm{~m}$ from one another and eight traps were placed in the plantation row and the other eight were placed in the between-row area, alternating in two plantation rows and two between-rows (sampling scheme in Fig. 1), and were left in the field for seven nights. Traps in the plantation row were placed in the south side of the canopy at $50 \mathrm{~cm}$ from the tree trunk. All captured individuals were sorted and determined to the species level (when possible).

\subsection{Carabid community traits}

To understand changes in carabid beetle communities along the land-use intensification gradient we analyzed the differences in species trait values, particularly of body size and dispersal ability, which are related to species sensitivity and response to disturbance (Kotze and O'hara, 2003; Ribera et al., 2001).

Species flight ability, as a proxy of dispersal ability, was classified according to their possession of full wings (macropterous $=1$; brachypterous/apterous $=0$; dimorphic $=0.5$ ). According to what is theoretically expected (e.g. Desender et al., 2010; Etienne and Olff, 2004) we established a gradient of dispersal ability power from the macropterous species (best dispersal within the species pool) to the brachypterous/apterous species (poorest dispersal ability within the species pool).

Information on all carabid beetle response traits (body size and flight ability) was collected from different sources (Appendix B). We calculated a community weighted trait mean, i.e. the mean trait value per sampling plot, to assess the impact of land-use intensification and/ or other environmental factors at different scales on carabid beetle communities. The community trait weighted means (CWM, hereafter) of both body size and dispersal ability were calculated as the relative abundance of a certain species multiplied by its trait value, summed over all species in the community (Garnier et al., 2004; Vandewalle et al., 2010). 


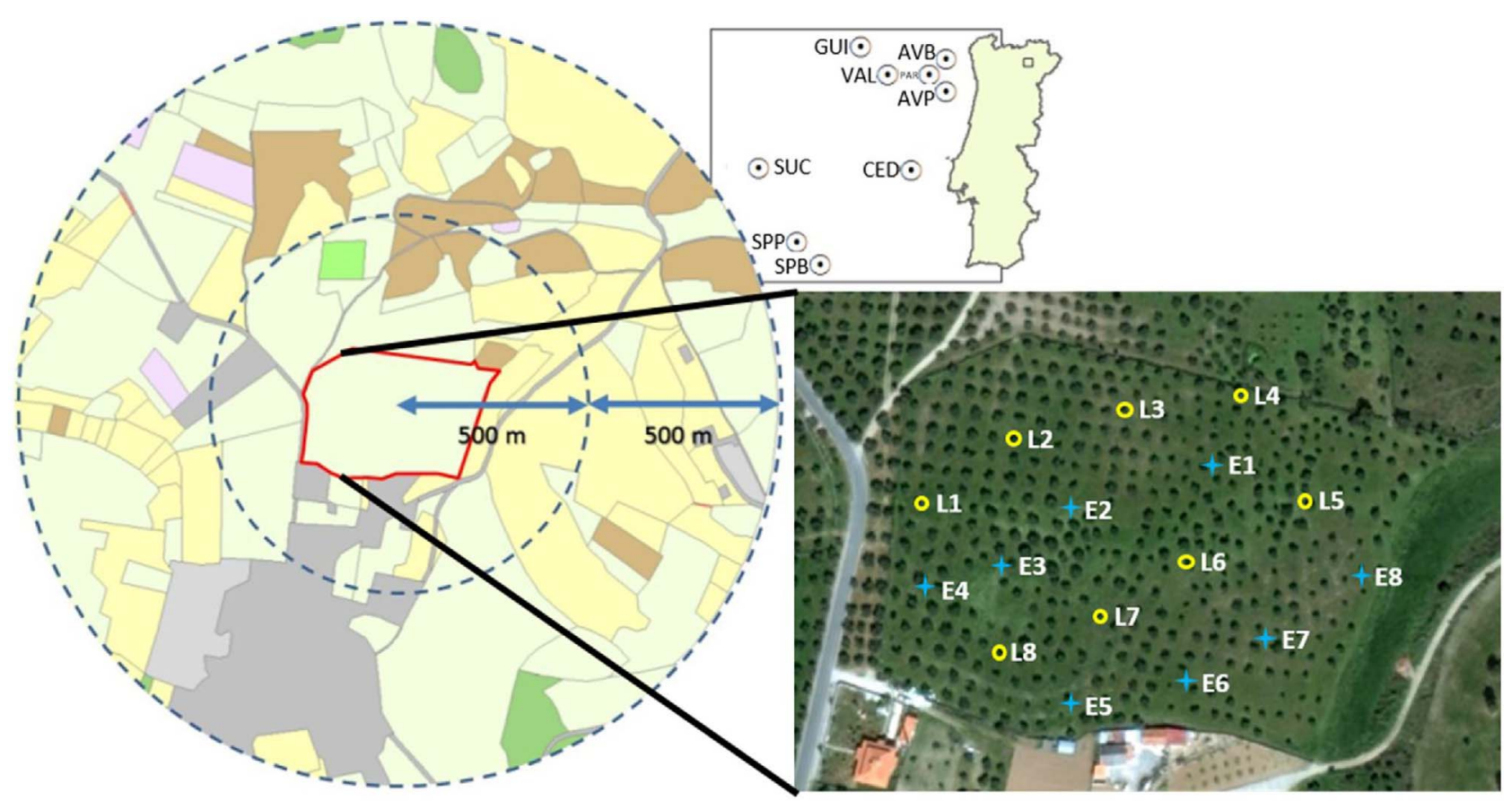

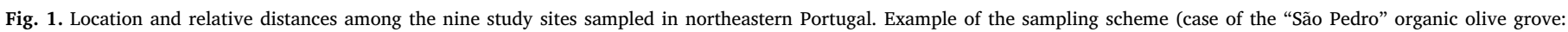

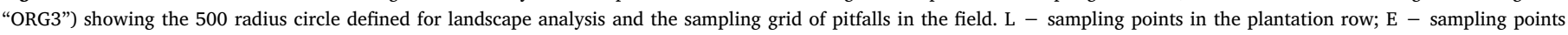
between tree rows. Distance between trees in this grove $-9 \mathrm{~m}$.

\subsection{Carabid diversity descriptors: response variables}

Carabid abundance $(\mathrm{N})$, species richness (S) and diversity (Simpson index: D) were calculated at each sampling point of the $4 \times 4$ grid across all olive groves. Functional diversity of different carabid community traits were also calculated using the Rao's quadratic entropy index (FD ${ }_{\mathrm{Q}}$ : Laliberté and Legendre, 2010; Rao, 1982) based on traits of species body size and dispersal ability (described above). For each sampling plot, $\mathrm{S}$ and $\mathrm{D}$, as well as $\mathrm{FD}_{\mathrm{Q}}$ and the community weighted mean (CWM) of body size and dispersal ability traits, were measured using the "FD" package (Laliberté and Legendre, 2010) implemented in the Statistical software R (R Core Team, 2014).

\subsection{Environmental variables at different levels}

\subsubsection{Olive grove management}

A land-use intensification index (LUI) was used to rank the different sites according to an intensification gradient of farming practices, such as it was previously proposed by Herzog et al. (2006) and Blüthgen et al. (2012) for other agricultural systems. The main farming practices registered in each olive grove included the intensity of fertilization applied by farmers, quantified by kg of nitrogen-potassium-phosphorous per ha per year, the livestock density, quantified by livestock (sheep) units days of grazing per ha per year, the frequency of mowing per year, the frequency of tillage per year and the doses of herbicides (applied to control weeds), fungicides (applied to control olive tree diseases) and insecticides (applied to control olive tree pests), quantified by liters of product, at recommended doses, per ha per year (Appendix A, Table A2 in Supplementary material; Appendix C). These practices are mostly related to fertilization, weed management and pesticide application that influence epigeous carabid beetles in different degrees (Döring and Kromp, 2003).

LUI was calculated by normalizing each farming practice and then, averaging them (Eq. (1)).

$$
L U I=\frac{\sum_{i=1}^{n}\left(y_{i}-y_{\min }\right) /\left(y_{\max }-y_{\text {min }}\right)}{n} \times 100
$$

Where $y_{i}$ is the observed value in an olive grove, $y_{\min }$ is the minimum observed value in the nine olive groves studied, $y_{\max }$ is the maximum observed value and $\mathrm{n}$ is the number of farming practices (i.e., seven).

\subsubsection{Landscape scale}

At the landscape scale, the main land-use classes (olive grove fields, agricultural land, shrub land, coniferous woodland, artificial areas) present across study sites were identified using aerial photographic interpretation methods (ESRI Word Imagery server, $1 \mathrm{~m}$ resolution, 2009) performed to a circle of $500 \mathrm{~m}$ radius centered in each site. To characterize the landscape configuration, a set of five landscape metrics from 3 different metric groups were calculated, namely patch density and size metrics (Number of patches - "NumP", Mean Patch Size "MPS" and Patch Size Standard Deviation - "SD(P.Size)"), edge metrics (Edge Density - "ED") and shape metrics (Mean Shape Index - "MSI") (McGarigal et al., 2002). Among the metrics of the first group, SD(P.Size) was included to provide an indication of landscape heterogeneity in terms of the variation of patch size of all land-use types composing the landscape mosaic.

Also, within a circle with $250 \mathrm{~m}$ radius centered in each study site, the area of the land-use type (classes: coniferous woodlands, shrubland, olive groves, urban and agricultural areas) of the surrounding patches in contiguity with the olive grove focal patch, was also extracted (Table 1). Remote sensing methods were combined with an in situ survey to confirm and correct for some recent land-use changes or photo misinterpretation. All map calculations and geoprocessing were conducted using ArcGIS 9.2 (ESRI, Redlands, California) and Patch Analyst 5.1 software (Rempel et al., 2012). 
Table 1

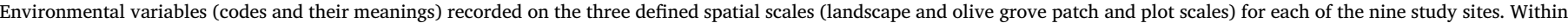
the landscape scale, metrics were extracted from three sub-levels (500 m radius, $250 \mathrm{~m}$ radius and line structures within olive patches).

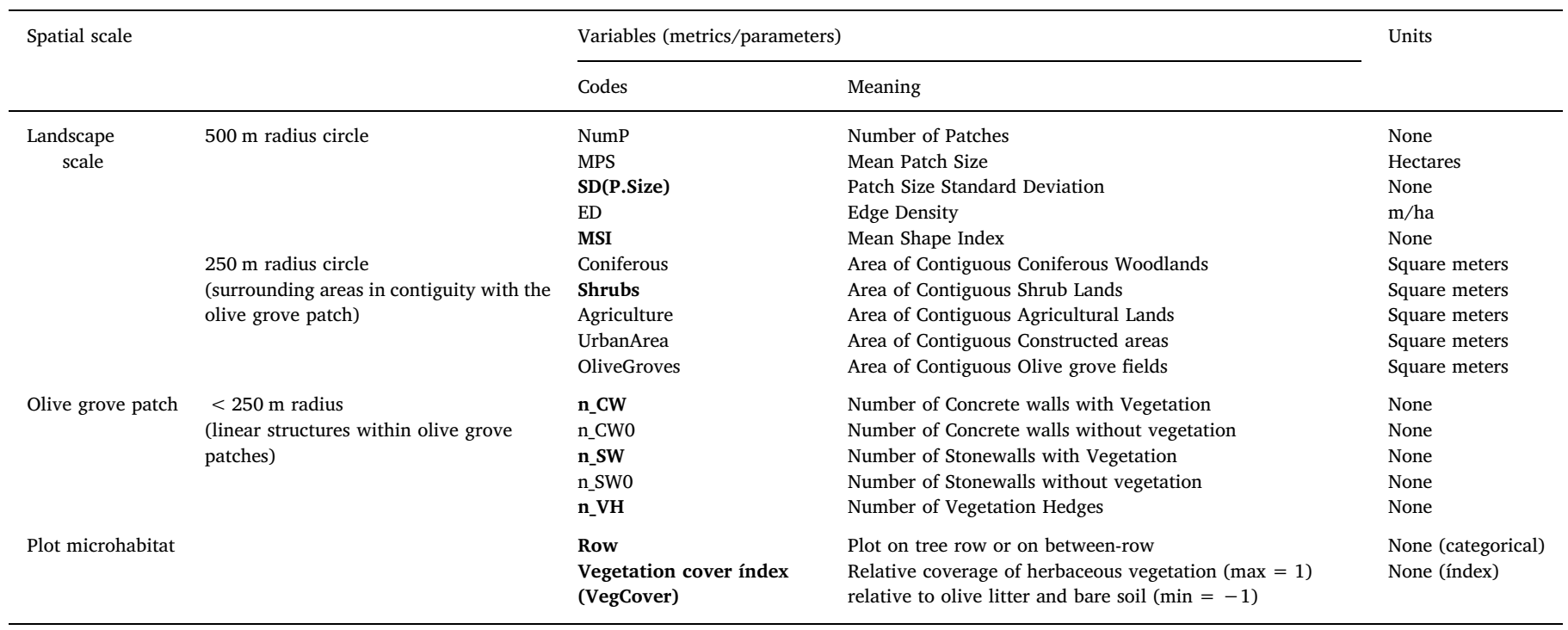

\subsubsection{Within the olive grove patches: patch and plot scales}

During the in situ survey we collected information on the presence, type and extent of all linear ecological structures (e.g. hedgerows, stonewalls) within each olive grove patch comprising the respective study site. This information was further included in the photo interpretation procedure, where linear structures were quantified and measured (number and total size of each type) within the area of the olive grove patch (Table 1, Appendix C). Considering that the $4 \times 4$ grid of sampling points corresponded basically to two lines of pitfall traps placed in the plantation row alternated with two lines of other pitfalls placed in between-row spaces (Fig. 1), these data were used also as microhabitat environmental variables (rows vs. between-rows) to check for the importance of tree microclimate conditions within olive groves (Table 1). At the plot level, considering the importance of herbaceous vegetation communities on carabid beetle diversity and community structure (e.g. Cole et al., 2006, 2010), data on the percentage of soil coverage with spontaneous herbaceous plants, olive leaf litter and bare soil were calculated using the quadrat method, with a total area of $4 \mathrm{~m}^{2}$, centered in each pitfall trap. In order to obtain from these different percentages of soil coverage a single environmental variable, we computed an index of vegetation cover (VegCover):

VegCover index $=\left[\frac{\% \text { Veg }}{\% \text { Total }} X(\%\right.$ Total $-\%$ Baresoil $\left.)\right] / 100$

where\%Total refers to the sum of the percentages of herbaceous plants and olive leaf litter. This index varies from " 1 " (100\% herbaceous vegetation cover) to "- 1 " (100\% bare soil), and values closer to zero mean that vegetation cover is mostly composed of olive leaf litter. Hence this VegCover index quantifies the cover type from green (herbaceous) vegetation via dead (leaf litter) to bare soil.

\subsection{Data analysis}

We performed Non-metric multidimensional scaling (NMDS) based on Bray-Curtis dissimilarity index to explore a pattern in carabid community structure among the different organic and integrated olive grove farms. For this analysis we used the most common carabid species found across all sites, comprising more than $90 \%$ of the total abundance. Constrained ordination methods were also applied to support the
NMDS results. Hence, a canonical correspondence analysis (CCA) was performed using $\log (\mathrm{x}+1)$ transformed data and based on the "sampling points vs. species", and "sampling points vs. olive groves or environmental variables" data matrices. We selected CCA after checking with Detrended Correspondence Analysis (DCA) that carabid communities showed strong unimodal response patterns to the spatialenvironmental gradient (Lepš and Smilauer, 2003). All management and environmental variables (at the landscape, patch and plot scales) were submitted to the CCA procedure of 'forward selection', in order to select the significant explanatory variables for community structure by sequential testing and eliminate redundant variables in the model (following Borcard et al., 1992). Statistical significance of the canonical axes was evaluated by a Monte Carlo permutation test (Leps and Smilauer, 2003). NMDS and CCA were performed in CANOCO 5.0 software.

General linear mixed models (GLMMs) were used to find the effects of environmental variables (landscape features, microhabitat conditions and management intensification) on the diversity response variables (N, S, FD_BS, FD_DA, CWM_BS and CWM_DA). The farming system type (variable "Organic", representing organic vs. integrated farms) was also added as a fixed factor. Olive grove sites (variable 'olive grove') were fitted as a random effect variable to account for spatial autocorrelation within sites. For each response variable a Bartlett's test was performed to test violations to the assumption of homogeneity of variance among olive grove sites (only in the case of $\mathrm{N}$ and $\mathrm{D}$ the tests were significant). In most cases (except for $\mathrm{N}$ and $\mathrm{D}$ ) the assumption of variance homogeneity was not violated, so we chose to transform the data only in the case of $\mathrm{N}$ and D (log-transformed). Since D after data transformation was still violating the assumption of homogeneity of variances we discarded this diversity descriptor from the analysis. Residual plots were also inspected to ensure assumptions of normality by using a Shapiro-Wilk test. Bartlett's test and Shapiro-Wilk test were performed using $\mathrm{R}$ base package "stats".

Among the fixed factors, most of the a priori selected landscape variables were excluded before performing GLMMs. The selection was based on scatterplots and Spearman correlation tests among all the explanatory variables: Those presenting strong linear correlations were dropped prior to the analysis. Hence, only three out of the ten initially selected landscape variables were used in the GLMM, namely the Patch 


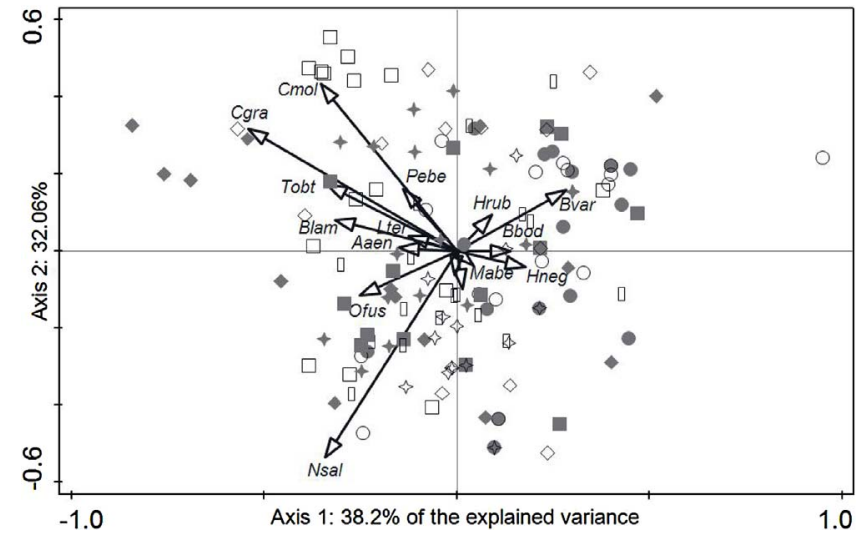

Fig. 2. NMDS based on carabid community structure of most common species sampled across all study sites (two species codes - "Hdis" and "Ossp" - were removed to make the graph clearer). Different symbols represent the different olive grove farms (closed symbols: organic farms; open symbols: integrated farms). NMDS stress value: 0.134.

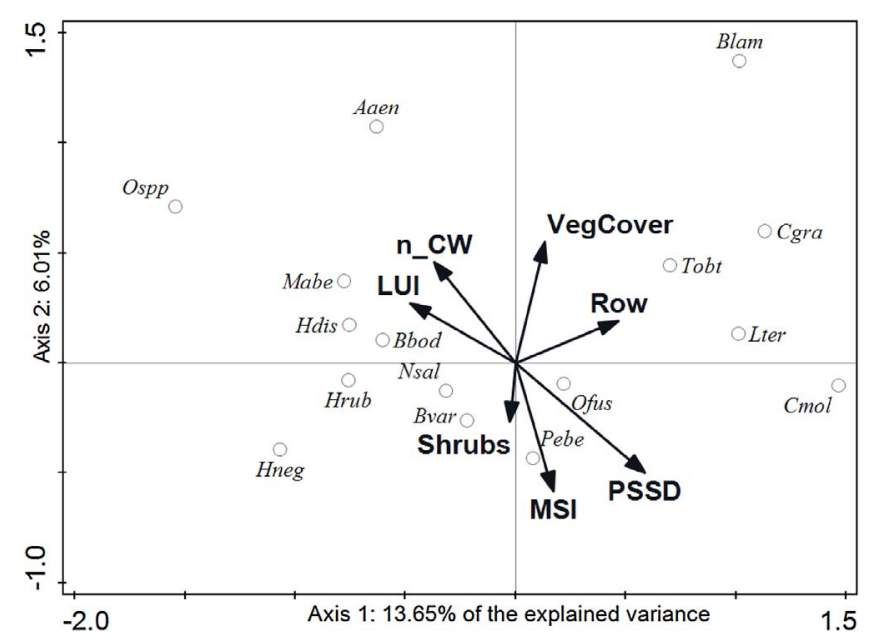

Fig. 3. CCA based on carabid community structure of most common species sampled across all study sites. Biplot showing the significant environmental variables after the procedure of forward selection: land-use intensification index (LUI) - management level; vegetation cover index (VegCover) - local level; number of concrete walls (n_CW) and row/between row effect (Row) - patch level; patch size standard deviation (SD(P.Size)), mean shape index (MSI) and area of contiguous shrub lands (Shrubs) - landscape level. Significance of canonical axes: Axis 1 : pseudo-F $=20.4, \mathrm{p}=0.002$; all canonical axes: pseudo-F $=6.9 ; \mathrm{p}=0.002$.

Size Standard Deviation (SD(P.Size)), Mean Shape Index (MSI) and the shrub area (that were the least correlated between each other). As well, the microhabitat plot and olive grove patch variables were reduced to five (Row, Vegetation cover, and number of linear structures: concrete walls with vegetation, stonewalls and vegetation hedges) out of the initial ten (Table 1). In addition, before using GLMM with all explanatory variables together (plot, patch and landscape variables), we used generalized linear models to excluded all variables with a variance inflation factor (VIF) higher than 3 in order to avoid multicollinearity (Graham, 2003). GLMs for variable selection were performed with Poisson log-link function in the case of S and Gaussian "identity" function for the other response variables (Fox and Weisberg, 2011). Then, for all the diversity descriptors (response variables) we performed GLMMs fitted by the Restricted Maximum Likelihood (REML) estimation method, using the remaining landscape, microhabitat and management variables as the fixed factors. F-tests (and the respective $\mathrm{p}$ values) were calculated by performing ANOVAs between the diversity descriptors and the fixed factors. These analyses were
Table 2

Summary of GLMM results for the number of species (S), Abundance $(\log N)$, and Rao functional diversity (FD) and community weighted means of body size and wing development traits (CWM). Statistically significant variables are in bold, with F-values presenting the numerator (ndf) and denominator (ddf) degrees of freedom. Random effects variable: olive grove sites (Groves). Fixed effects variables: land use intensification index (LUI); Patch Size Standard Deviation (SD(P.Size)), Mean Shape Index (MSI); plot on tree row or on between-row (Row), vegetation cover index (VegCover), number of concrete walls with vegetation (n_CW).

\begin{tabular}{|c|c|c|c|c|}
\hline Response variable & Fixed effects & Estimate & $F_{(n d f, d d f)}$ & $P$ value \\
\hline $\begin{array}{l}\text { Number of species }(S) \\
\text { (Random effects estimate: } \\
\text { Groves }=0.308 \text {; Residual } \\
\text { variance }=2.06 \text { ) }\end{array}$ & $\begin{array}{l}\text { Organic } \\
\text { LUI } \\
\text { MSI } \\
\text { Row } \\
\text { VegCover } \\
\text { n_CW }\end{array}$ & $\begin{array}{l}0.698 \\
0.007 \\
0.860 \\
0.390 \\
1.013 \\
0.448\end{array}$ & $\begin{array}{l}2.48_{(1,4)} \\
0.27_{(1,4)} \\
2.38_{(1,4)} \\
0.80_{(1,128)} \\
8.21_{(1,128)} \\
15.4_{(1,4)}\end{array}$ & $\begin{array}{l}0.190 \\
0.629 \\
0.198 \\
0.373 \\
\mathbf{0 . 0 0 5} \\
\mathbf{0 . 0 1 7}\end{array}$ \\
\hline $\begin{array}{l}\text { Abundance }(\log \mathrm{N}) \\
\text { (Random effects estimate: } \\
\text { Groves }=0.053 \text {; Residual } \\
\text { variance }=0.37 \text { ) }\end{array}$ & $\begin{array}{l}\text { Organic } \\
\text { LUI } \\
\text { SD(P.Size) } \\
\text { Row } \\
\text { VegCover } \\
\text { n_CW }\end{array}$ & $\begin{array}{l}0.284 \\
0.006 \\
0.238 \\
0.000 \\
0.174 \\
0.106\end{array}$ & $\begin{array}{l}6.70_{(1,4)} \\
0.03_{(1,4)} \\
0.18_{(1,4)} \\
0.09_{(1,128)} \\
8.81_{(1,128)} \\
10.9_{(1,4)}\end{array}$ & $\begin{array}{l}0.061 \\
0.875 \\
0.696 \\
0.765 \\
\mathbf{0 . 0 0 4} \\
\mathbf{0 . 0 3 0}\end{array}$ \\
\hline $\begin{array}{l}\text { FD_BodySize } \\
\text { (Random effects estimate: } \\
\text { Groves }<0.001 \text {; Residual } \\
\text { variance }=1.65 \text { ) }\end{array}$ & $\begin{array}{l}\text { Organic } \\
\text { LUI } \\
\text { SD(P.Size) } \\
\text { Row } \\
\text { VegCover } \\
\text { n_CW }\end{array}$ & $\begin{array}{l}0.210 \\
-0.113 \\
-0.006 \\
0.134 \\
0.311 \\
0.072\end{array}$ & $\begin{array}{l}0.24_{(1,4)} \\
3.76_{(1,4)} \\
0.98_{(1,4)} \\
0.14_{(1,128)} \\
1.13_{(1,128)} \\
0.29_{(1,4)}\end{array}$ & $\begin{array}{l}0.650 \\
0.125 \\
0.378 \\
0.709 \\
0.289 \\
0.619\end{array}$ \\
\hline $\begin{array}{l}\text { FD_WingDevelopment } \\
\text { (Random effects estimate: } \\
\text { Groves }=0.027 \text {; Residual } \\
\text { variance }=0.12 \text { ) }\end{array}$ & $\begin{array}{l}\text { Organic } \\
\text { LUI } \\
\text { SD(P.Size) } \\
\text { Row } \\
\text { VegCover } \\
\text { n_CW }\end{array}$ & $\begin{array}{l}0.020 \\
-0.011 \\
0.051 \\
0.036 \\
0.034 \\
0.005\end{array}$ & $\begin{array}{l}0.23_{(1,4)} \\
9.34_{(1,4)} \\
2.85_{(1,4)} \\
2.67_{(1,128)} \\
1.61_{(1,128)} \\
0.11_{(1,4)}\end{array}$ & $\begin{array}{l}0.655 \\
\mathbf{0 . 0 3 8} \\
0.167 \\
0.104 \\
0.207 \\
0.761\end{array}$ \\
\hline $\begin{array}{l}\text { CWM_BodySize } \\
\text { (Random effects estimate: } \\
\text { Groves }<0.001 \text {; Residual } \\
\text { variance }=2.11 \text { ) }\end{array}$ & $\begin{array}{l}\text { Organic } \\
\text { LUI } \\
\text { SD(P.Size) } \\
\text { Row } \\
\text { VegCover } \\
\text { n_CW }\end{array}$ & $\begin{array}{l}0.786 \\
-0.174 \\
1.277 \\
1.656 \\
0.126 \\
0.082\end{array}$ & $\begin{array}{l}2.04_{(1,4)} \\
16.2_{(1,4)} \\
11.2_{(1,4)} \\
20.9_{(1,128)} \\
0.05_{(1,128)} \\
0.18_{(1,4)}\end{array}$ & $\begin{array}{l}0.227 \\
\mathbf{0 . 0 1 6} \\
\mathbf{0 . 0 2 8} \\
<\mathbf{0 . 0 0 1} \\
0.824 \\
0.691\end{array}$ \\
\hline $\begin{array}{l}\text { CWM_WingDevelopment } \\
\text { (Random effects estimate: } \\
\text { Groves }=0.084 \text {; Residual } \\
\text { variance }=0.18 \text { ) }\end{array}$ & $\begin{array}{l}\text { Organic } \\
\text { LUI } \\
\text { SD(P.Size) } \\
\text { Row } \\
\text { VegCover } \\
\text { n_CW }\end{array}$ & $\begin{array}{l}0.058 \\
0.014 \\
-0.027 \\
-0.038 \\
-0.098 \\
0.020\end{array}$ & $\begin{array}{l}0.36_{(1,4)} \\
3 \cdot 54_{(1,4)} \\
1.93_{(1,4)} \\
1.07_{(1,128)} \\
3.24_{(1,128)} \\
0.45_{(1,4)}\end{array}$ & $\begin{array}{l}0.581 \\
0.133 \\
0.237 \\
0.304 \\
0.074 \\
0.541\end{array}$ \\
\hline
\end{tabular}

performed in the R package "lmerTest" version 2.0-20 (Kuznetsova et al., 2014). Finally we used GLM tests as post hoc planned comparisons on the GLMM partial residuals to reveal the relationships between the response variables and the main fixed factors detected in the model. GLM were performed using R base package "car" (Fox and Weisberg, 2011) and post hoc effect plots were obtained using the $\mathrm{R}$ package "effects" version 2.3-0 (Fox et al., 2013).

\section{Results}

Overall, 1648 carabid beetles distributed among 54 species/morphospecies were collected. A total of 725 carabid beetles belonging to 41 species/morphospecies were sampled in spring, whereas 923 carabids distributed by 34 taxa were recorded in autumn. Nebria salina Fairmaire \& Laboulbénè, 1854, followed by Pterostichus ebenus (Quensel, 1806) and Calathus mollis (Marsham, 1802) were the dominant species collected in pitfalls over the two sampling seasons, representing respectively $29.4 \%, 13.9 \%$ and $9.2 \%$ of the total carabid beetles collected (most abundant species in each sampling period in 


\section{n_CW effect plot}

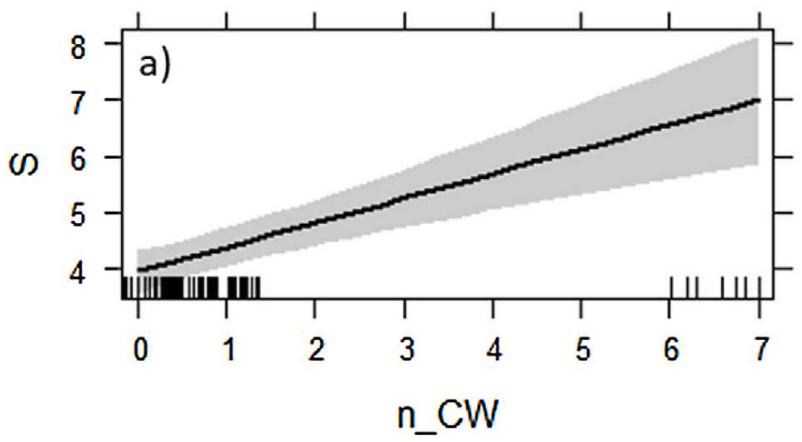

\section{LUI effect plot}

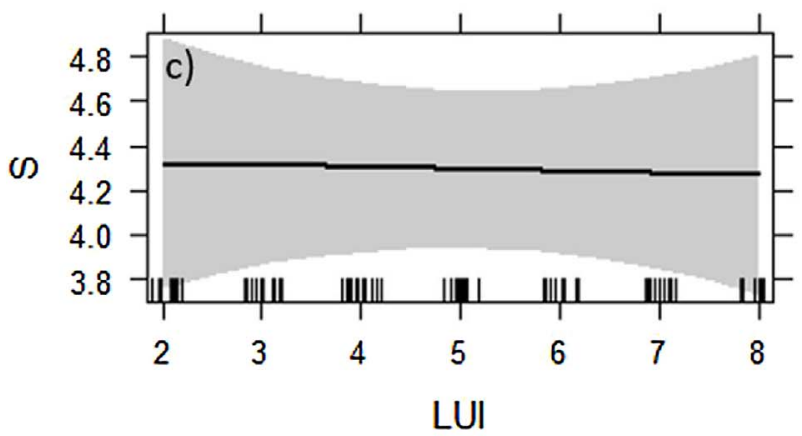

VegCover effect plot

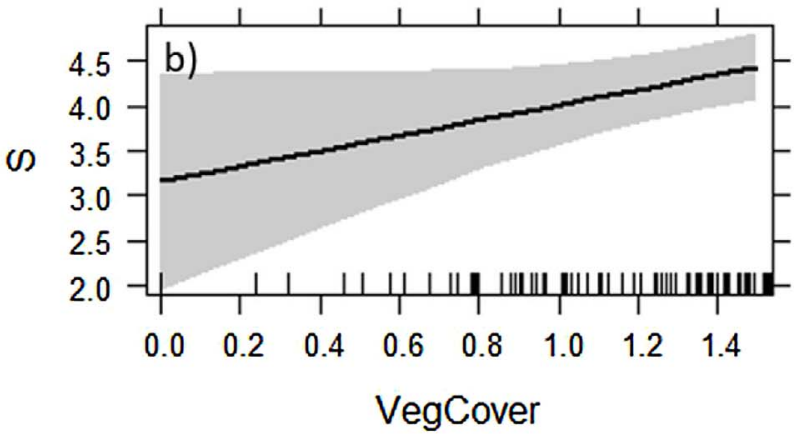

\section{Organic effect plot}

$\omega$

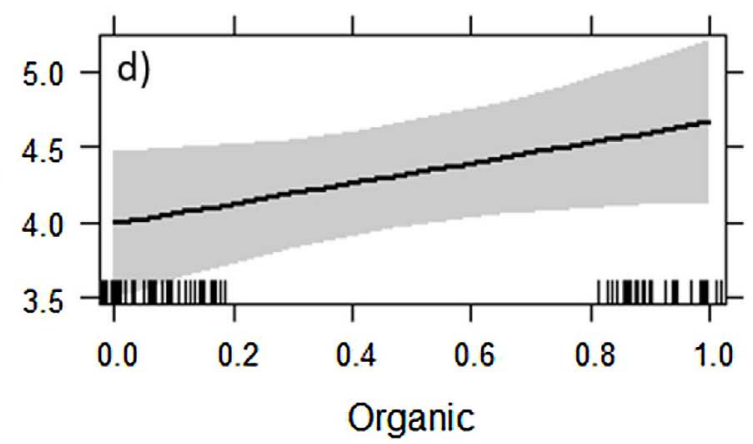

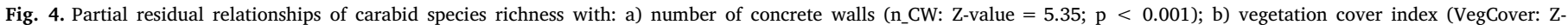
value $=3.28 ; \mathrm{p}=0.001), \mathrm{c}$ ) land-use intensification index (LUI: $\mathrm{Z}$-value $=0.59 ; \mathrm{p}=0.558$ ) and $\mathrm{d}$ ) farming system $($ Organic: $\mathrm{Z}$-value $=-0.13$; $\mathrm{p}=0.896$ )

Appendix D).

The NMDS based on the most common species (comprising more than $90 \%$ of the total abundance) did not reveal a clear pattern separating among organic and integrated olive groves (Fig. 2). Moreover, the farming system variable (organic vs. integrated) was not selected by the CCA procedure of forward selection. Only seven environmental variables were significantly explaining the differences in carabid community structure among olive groves: a) LUI (management intensity); b) VegCover index (local level); c) number of concrete walls with vegetation (" $n_{-} C W$ ") and the row/between row variable ("Row"), at the patch level); d) Patch Size Standard Deviation ("SD (P.Size)"), Mean Shape Index ("MSI") and the shrub area ("Shrubs"), at the landscape level (Fig. 3). All these variables together accounted for $23.2 \%$ of the total explained variance across olive grove sites (first two axes explained ca. 20\%). Some carabid species, e.g. Calathus granatensis Vuillefroy, 1866 and C. mollis ("Cgra" and "Cmol" in the graph), seemed to be associated to particular environmental features at the local, patch and landscape levels (Fig. 3).

GLMM analysis using olive grove sites as random factors suggested that environmental factors across different scales (the type of vegetation coverage at the fine plot scale, linear structures at the olive grove patch scale, and the heterogeneity in patch size of the habitats composing the landscape mosaic) are important drivers of carabid diversity changes in olive groves (Table 2). The farming system (factor "Organic") was not significantly related to any response variable (Table 2; Figs. 4-7). The LUI gradient along the olive groves also did not influence carabid beetle richness (Fig. 4) and abundance (Fig. 5). Yet, the LUI gradient was related to some descriptors of functional diversity, namely FD of dispersal ability (Table 2) and CWM of carabid body size (Table 2, Fig. 6).

Species richness and abundance increased with a higher percentage of herbaceous vegetation cover at the plot level and with the amount of concrete walls with vegetation at the olive grove patch level (Figs. 4 and 5). Higher percentage of vegetation cover was associated to a higher relative abundance of poorer dispersers (i.e. prevalence of brachypterous species) in carabid communities at the plot scale (Fig. 7), while at the scale of the olive grove a prevalence of larger sized species was found along the plantation rows in relation to the open 'between-row' areas (Fig. 6).

At the landscape scale, a higher variance in patch size of all land-use types within the landscape mosaic (SD(P.Size)) affected carabid beetle community traits of body size and dispersal ability. SD(P.Size) was related to an increase in average carabid body size (Fig. 6) and supported a higher frequency of poorer dispersers, although the effect of SD(P.Size) on CWM_DA was not significant in the GLMM model (Table 2, Fig. 7).

\section{Discussion}

Our results showed that the farming system type in general such as organic and conventional did not have a significant effect on carabid beetle communities across the studied olive groves. Despite the known impact of land-use intensification on biodiversity patterns (e.g. Woodcock et al., 2005), several studies have shown that the beneficial effects of lower intensively managed agroecosystems in relation to conventional (or integrated) agriculture are context dependent and rely on an array of other environmental factors at different spatial scales (e.g. Bengtsson et al., 2005; Dauber et al., 2003; Diekötter et al., 2010; 


\section{n_CW effect plot}

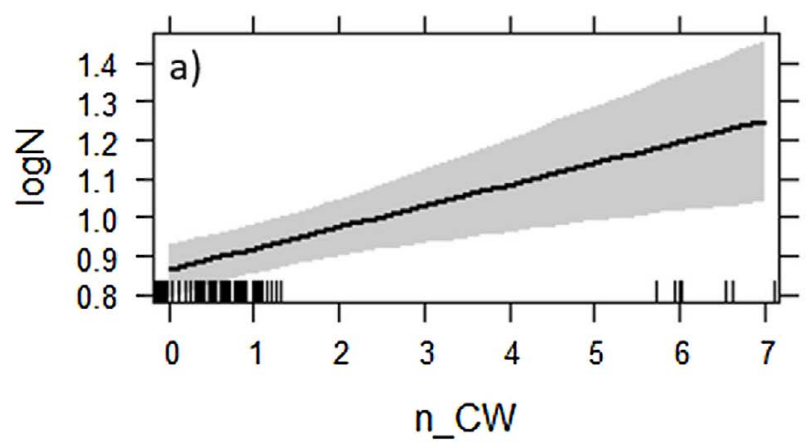

LUI effect plot

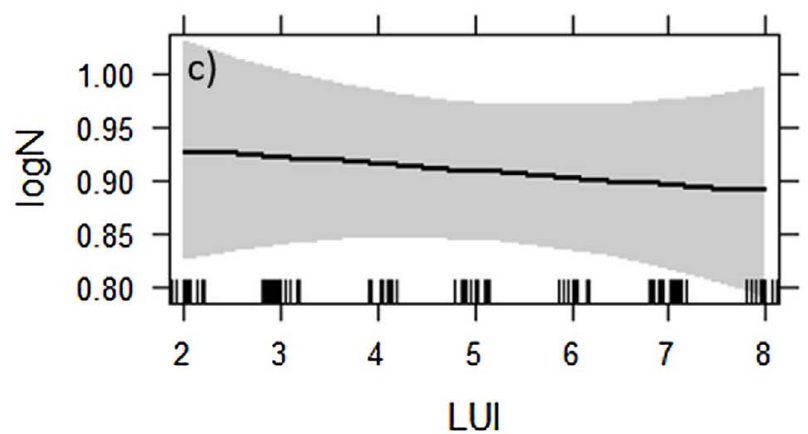

VegCover effect plot

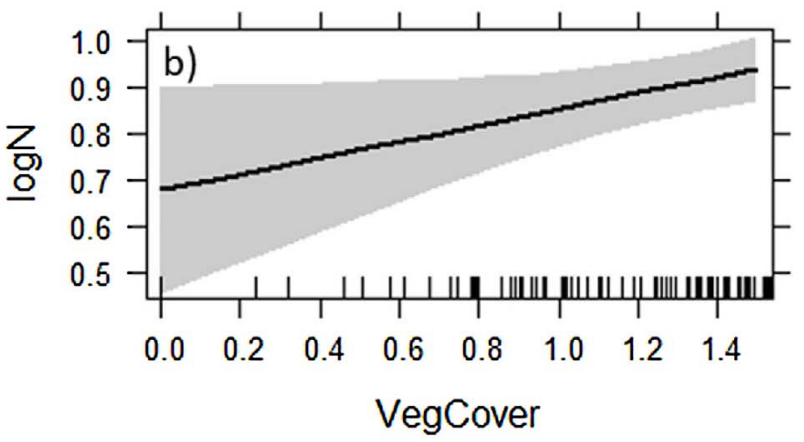

\section{Organic effect plot}

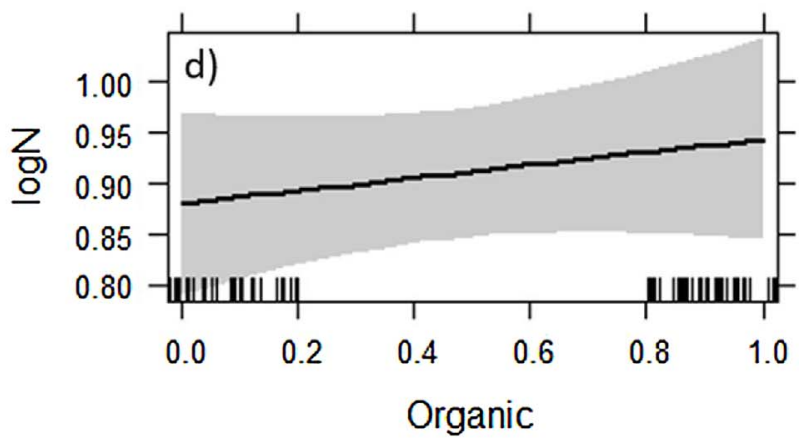

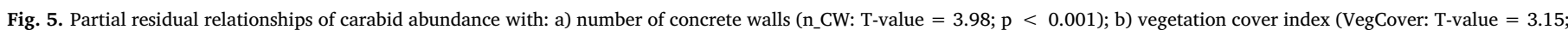
$\mathrm{p}=0.002$ ), $\mathrm{c}$ ) land-use intensification index (LUI: $\mathrm{T}$-value $=-0.21 ; \mathrm{p}=0.834$ ) and $\mathrm{d}$ ) farming system (Organic: $\mathrm{T}$-value $=-0.554 ; \mathrm{p}=0.58$ ).

Flohre et al., 2011; Maisonhaute et al., 2010; Sarthou et al., 2014).

Accordingly, in this study, changes in carabid abundance and species richness were mainly influenced by specific features of the olive groves, particularly by the ecological linear structures and habitat conditions at a finer spatial scale. Management intensity levels (measured by the LUI index) and environmental features at different scales influenced the trait structure of carabid communities. This result supports our hypothesis that the farming system by definition (whether it is organic or integrated farming) is not sufficient to predict functional diversity and community traits of carabid beetles, if specific management practices and olive grove characteristics are not taken into account. In fact, the application of the LUI index showed that a separation between organic and integrated olive groves according to their inherent management practices may not be a straightforward task.

Also, we found that community traits associated to sensitiveness to land-use management were influenced by landscape and local features supporting refuge habitats for carabid beetles. Hence, in line with previous studies (e.g. Barbaro and van Halder, 2009; Döring and Kromp, 2003; Hanson et al., 2016; Ribera et al., 2001; Vanbergen et al., 2010; Vandewalle et al., 2010; Woodcock et al., 2010) our results support the use of community traits as indicators of habitat structure and land-use disturbance.

\subsection{Effects of environmental factors on carabid diversity}

Among all environmental variables, the local features at the plot or patch scales were in general the main factors explaining diversity differences of carabid communities across olive groves. For many invertebrates, contrasting microclimate conditions and fine-scale habi- tat heterogeneity may be more important than the effect of farm management (Cole et al., 2010). In effect, previous studies have showed that the microhabitat is a determinant factor for carabid beetle diversity and community composition (e.g. Betbeder et al., 2015; Koivula et al., 1999; Kotze et al., 2011; Niemelä et al., 1992; Schirmel et al., 2015). Here we found that carabid abundance and species richness were higher in spots with denser vegetation cover (plot scale). Although the structure of the vegetation cover may be a result of land-use intensification, the possible overlap of the effects of these two factors was controlled in the procedure of variable selection. Also, this positive association between green vegetation coverage and carabid species richness may be an indication of a seasonal effect. In fact, a higher number of carabid species was collected in spring in relation to autumn.

Abundance and species richness were also supported by ecological linear structures (patch scale), in particular walls with vegetation within the olive grove patches. This finding supports the common notion that non-cropped areas, such as field margins, hedgerows and other small habitats, provide shelter (e.g. overwintering refuge) for many species (Cole et al., 2010; MacLeod et al., 2004; Woodcock et al., 2005). These ecological structures may serve as source areas for many species, and so influencing the number of species within the agricultural landscape (Eyre et al., 2016; Werling and Gratton, 2008; Woodcock et al., 2005).

\subsection{Effects of management and environmental features on carabid response} traits

There is growing evidence that large-bodied and short-winged carabid species tend to be more sensitive to land-use intensification, 


\section{SD_P.Size effect plot}

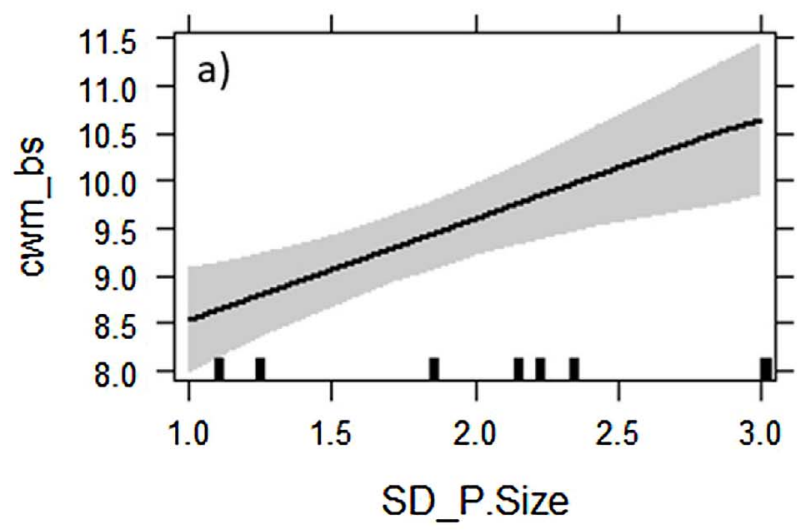

LUI effect plot

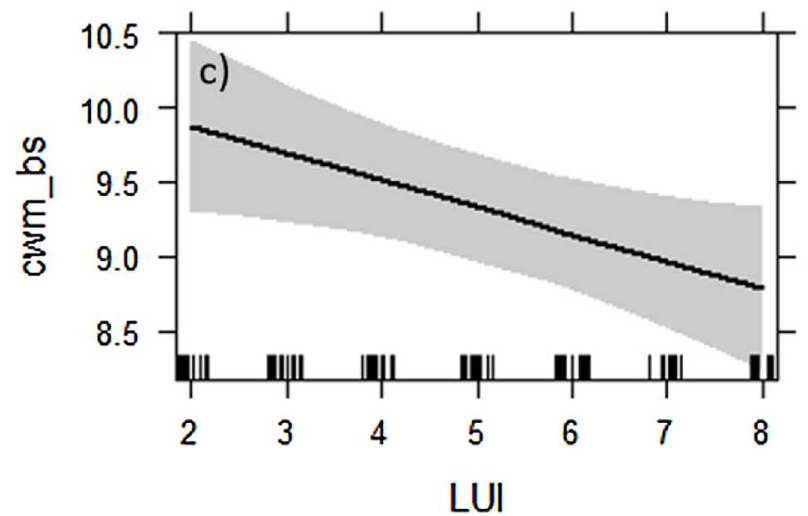

\section{Row effect plot}

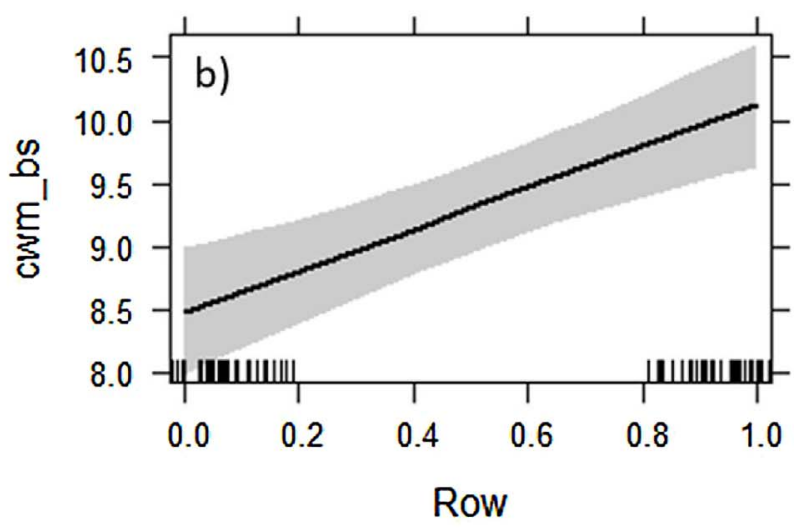

Organic effect plot

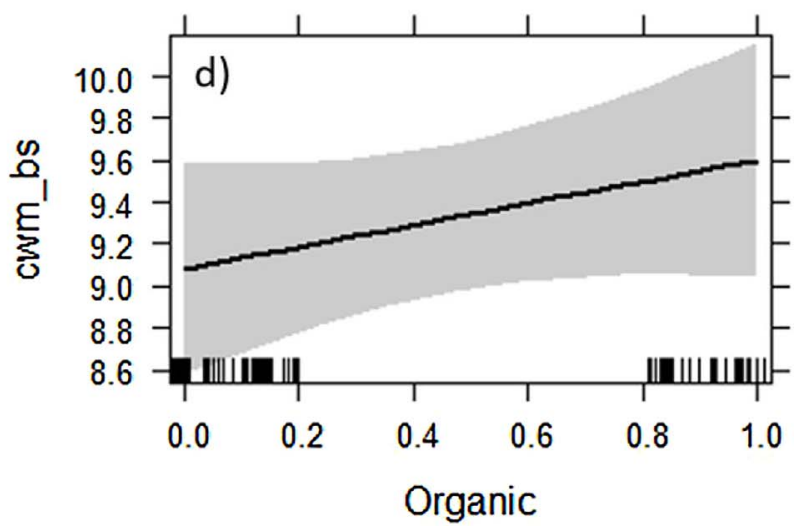

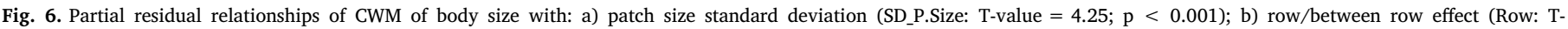
value $=4.22 ; \mathrm{p}<0.001$ ), $\mathrm{c}$ ) land-use intensification index (LUI: T-value $=-3.66 ; \mathrm{p}<0.001$ ) and $\mathrm{d}$ ) farming system $($ Organic: $\mathrm{T}$-value $=-0.82 ; \mathrm{p}=0.413$ )

so they are more prone to decline with habitat disturbance than smallbodied and dimorphic species (e.g. Hanson et al., 2016; Kotze and O'Hara, 2003; Ribera et al., 2001; Spake et al., 2016). Our results are in line with this perception: community traits of body size were negatively related with the gradient of land-use intensification, while community traits of wing development were positively related to management intensification. Our land-use intensification index incorporated both physical and chemical disturbances, such as tillage activities and agrochemical inputs. These have been reported to affect more severely the large body-sized carabid beetles than smaller carabid species (e.g. Hanson et al., 2016; Rusch et al., 2013), due to a number of reasons (see, for instance: Kotze and O'Hara, 2003; Ribera et al., 2001). Previous studies also showed that the average body size of carabid beetle communities is also related to the habitat configuration, particularly the vegetation structure and canopy cover in agricultural and forested ecosystems (e.g. Brose 2003; Spake et al., 2016; Vandewalle et al., 2010; Woodcock et al., 2005).

Here, larger carabid species were more frequent along the plantation rows, indicating that these species may have found there a refuge against predators (Brose, 2003) and/or the preferred microclimate conditions (e.g. moisture) supported by the olive trees (e.g., Eyre et al., 2016; Schirmel et al., 2015). Also, a higher proportion of brachypterous species was associated to plots of denser vegetation cover. Wing development was used as a proxy of dispersal ability. Thus, a higher number of poorer dispersers preferred the sheltered habitat conditions promoted by thicker spots of herbaceous plants at the fine plot scale. Previous studies showed that active microhabitat selection explains carabid species distributions at the small scale within the study areas (Koivula et al., 1999; Kotze et al., 2011; Niemelä et al., 1992). Different species characteristics and species interactions may underlie such species distributions and community structuring at local spatial scales (Koivula et al., 1999), as a result of niche partitioning and species tradeoffs (Driscoll, 2008).

Besides the habitat conditions at the fine-scale, the landscape metric "Patch Size Standard Deviation" was also related to variations in carabid community traits, especially in terms of species body size. We found that larger carabid species were associated to landscape configurations with higher variance in terms of the patch size of the land-use types surrounding the targeted olive grove patches. In fact, the structure and heterogeneity of the surrounding habitats has been proven to influence carabid diversity patterns occurring within the agricultural areas (e.g. Maisonhaute et al., 2010; Petit and Usher, 1998; Purtauf et al., 2005; Sarthou et al., 2014; Vanbergen et al., 2010; Woodcock et al., 2010). It this study the higher variability in patch size within the landscape mosaic has probably reflected the importance of the mixed use of different habitat types in supporting larger carabid species in olive groves. This result indicates that the landscape configuration may enhance the frequency of sensitive carabid beetles in the olive grove agroecosystems and, ultimately, influence positively the important role of pest control in olive groves. 


\section{SD_P.Size effect plot}

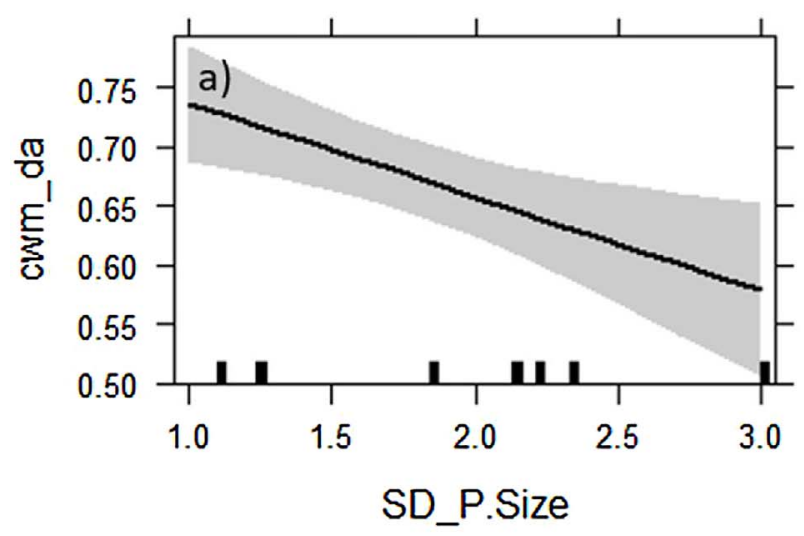

LUI effect plot

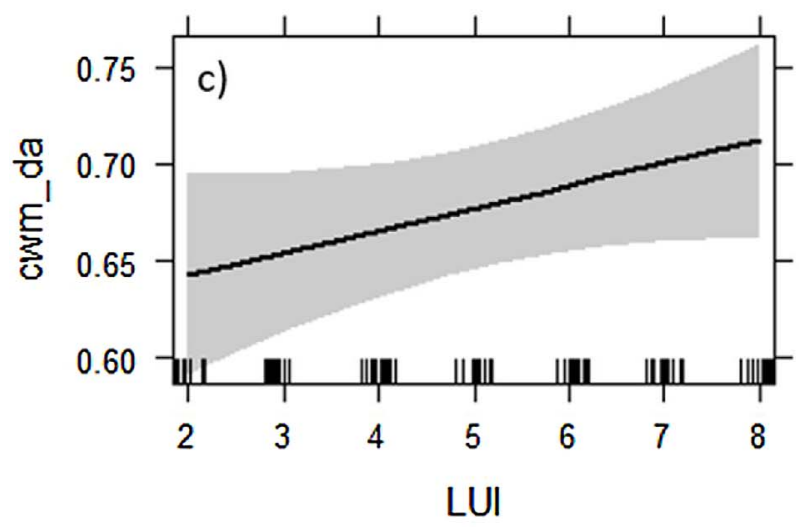

\section{VegCover effect plot}

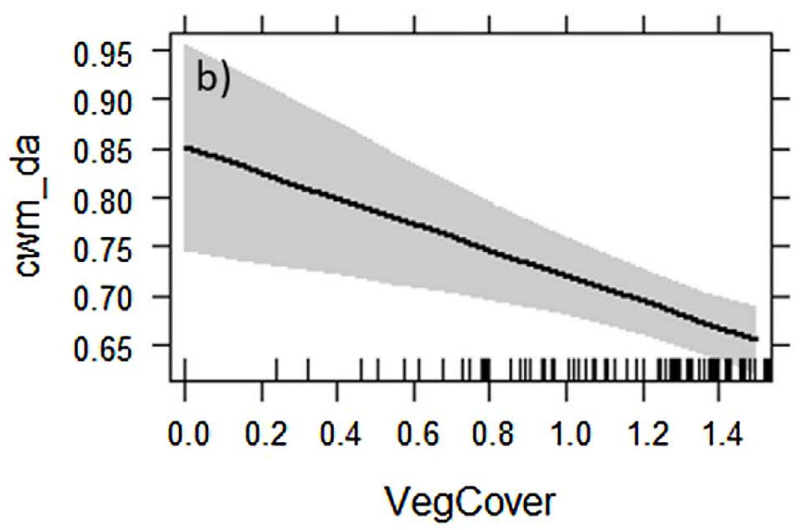

Organic effect plot

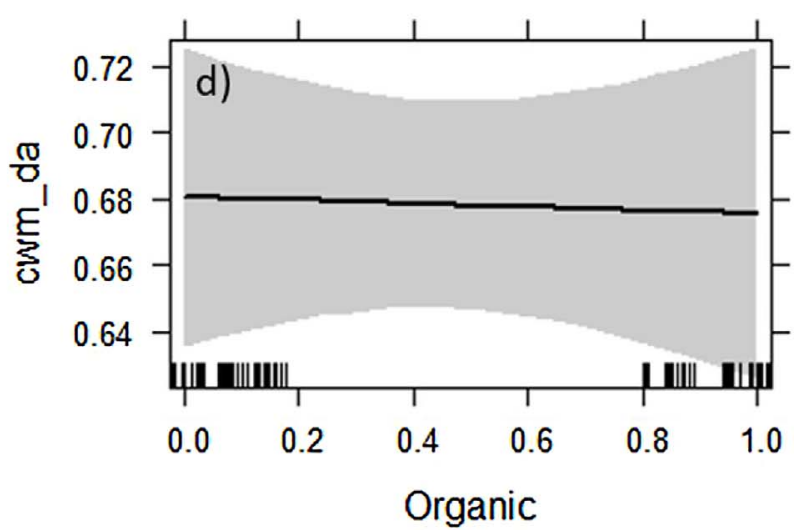

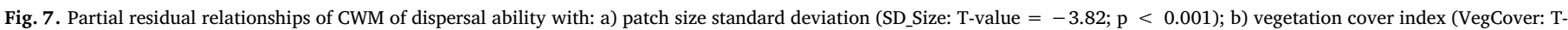
value $=-3.32 ; \mathrm{p}=0.001$ ), c) land-use intensification index (LUI: T-value $=3.55 ; \mathrm{p}<0.001$ ) and d) farming system (Organic: T-value $=1.94 ; \mathrm{p}=0.054$ ).

\section{Conclusions}

Our findings support the notion that other environmental factors besides management practices play a key role on influencing community structure in agroecosystems such as the olive groves. Effects of land-use intensity are contingent to the specific landscape configuration and especially the local features that shape carabid diversity patterns and community traits linked to sensitiveness to disturbance. In this sense the use of community traits is a promising management tool to apply in conservation studies using bioindicators, as they may provide mechanistic understanding on how ecological processes at different scales drive community changes in olive groves. Conservation initiatives and management planning need to take into consideration the small-scale architecture and landscape configuration of olive groves. Particularly, the existence of linear structures with green vegetation within the olive grove patches may provide shelter for various carabid beetle species, especially those more sensitive to land-use disturbance. Also a mixed use of the olive grove landscapes is recommended to protect carabid beetle diversity and ultimately to help to assure the sustainability of pest control in olive grove agroecosystems.

\section{Acknowledgments}

The authors would like to thank all farmers who allowed our access to their olive groves. This work and the writing of this manuscript was funded by Portuguese Foundation for Science and Technology (FCT) through the project PTDC/AGR-PRO/111123/2009 (The use of biolo- gical indicators as tools for assessing the impact of agricultural practices in sustainability of olive grove) and the project BiodivERsA/001/2014 (ECOSERVE - Sustainable provisioning of multiple ecosystem services in agricultural landscapes). P. Martins da Silva was supported by the Portuguese Foundation for Science and Technology (SFRH/BPD/ 109511/2015). The authors are indebted to two anonymous reviewers who helped to improve a previous version of this study.

\section{Appendix A. Supplementary data}

Supplementary data associated with this article can be found, in the online version, at http://dx.doi.org/10.1016/j.ecolind.2017.04.022.

\section{References}

Barbaro, L., van Halder, I., 2009. Linking bird, carabid beetle and butterfly life-history traits to habitat fragmentation in mosaic landscapes. Ecography 32, 321-333. http:// dx.doi.org/10.1111/j.1600-0587.2008.05546.x.

Bengtsson, J., Ahnström, J., Weibull, A.-C., 2005. The effects of organic agriculture on biodiversity and abundance: a meta-analysis. J. Appl. Ecol. 42, 261-269. http://dx. doi.org/10.1111/j.1365-2664.2005.01005.x.

Betbeder, J., Hubert-Moy, L., Burel, F., Corgne, S., Baudry, J., 2015. Assessing ecological habitat structure from local to landscape scales using synthetic aperture radar. Ecol Ind. 52, 545-557. http://dx.doi.org/10.1016/j.ecolind.2014.11.009.

Blüthgen, N., Dormann, C.F., Prati, D., Klaus, V.H., Kleinebecker, T., Hölzel, N., Alt, F., Boch, S., Gockel, S., Hemp, A., Müller, J., Nieschulze, J., Renner, S.C., Schöning, I., Schumacher, U., Socher, S.A., Wells, K., Birkhofer, K., Buscot, F., Oelmann, Y., Rothenwöhrer, C., Scherber, C., Tscharntke, T., Weiner, C.N., Fischer, M., Kalko, E.K.V., Linsenmair, K.E., Schulze, E.D., Weisser, W.W., 2012. A quantitative index of land-use intensity in grasslands: Integrating mowing, grazing and fertilization. Basic 
Appl. Ecol. 13, 207-220. http://dx.doi.org/10.1016/j.baae.2012.04.001.

Borcard, D., Legendre, P., Drapeau, P., 1992. Partialling out the spatial component of ecological variation. Ecology 73, 1045-1055. http://dx.doi.org/10.2307/1940179.

Brose, U., 2003. Bottom-up control of carabid beetle communities in early successional wetlands: mediated by vegetation structure or plant diversity? Oecologia 135 , 407-413.

Cardarelli, E., Bogliani, G., 2014. Effects of grass management intensity on ground beetle assemblages in rice field banks. Agric. Ecosyst. Environ. 195, 120-126. http://dx.doi. org/10.1016/j.agee.2014.05.004

Cole, L.J., Pollock, M.L., Robertson, D., Holland, J.P., McCracken, D.I., 2006. Carabid (Coleoptera) assemblages in the Scottish uplands: the influence of sheep grazing on ecological structure. Entomol. Fennica 17, 229-240. http://hdl.handle.net/11262/ 7468.

Cole, L.J., Pollock, M.L., Robertson, D., Holland, J.P., McCracken, D.I., Harrison, W. 2010. The influence of fine-scale habitat heterogeneity on invertebrate assemblage structure in upland semi-natural grassland. Agric. Ecosyst. Environ. 136, 69-80. http://dx.doi.org/10.1016/j.agee.2009.11.010.

Döring, T.F., Kromp, B., 2003. Which carabid species benefit from organic agriculture? A review of comparative studies in winter cereals from Germany and Switzerland. Agric. Ecosyst. Environ. 98, 153-161. http://dx.doi.org/10.1016/S0167-8809(03) 00077-X.

Daane, K.M., Johnson, M.W., 2010. Olive fruit fly: managing an ancient pest in modern times. Ann. Rev. Entomol. 55, 151-169. http://dx.doi.org/10.1146/annurev.ento.54. 110807.090553.

Dauber, J., Mirsch, M., Simmering, D., Waldhardt, R., Otte, A., Wolters, V., 2003. Landscape structure as an indicator of biodiversity: matrix effects on species richness. Agric. Ecosyst. Environ. 98, 321-329. http://dx.doi.org/10.1016/S0167-8809(03) 00092-6.

Desender, K., Dekoninck, W., Dufrêne, M., Maes, D., 2010. Changes in the distribution of carabid beetles in Belgium revisited: have we halted the diversity loss? Biol. Conserv. 143, 1549-1557. http://dx.doi.org/10.1016/j.biocon.2010.03.039.

Diekötter, T., Wamser, S., Wolters, V., Birkhofer, K., 2010. Landscape and managemen effects on structure and function of soil arthropod communities in winter wheat. Agric. Ecosyst. Environ. 137, 108-112. http://dx.doi.org/10.1016/j.agee.2010.01. 008.

Dinis, A.M., Pereira, J.A., Benhadi-Marín, J., Santos, S.A.P., 2016. Feeding preferences and functional responses of Calathus granatensis and Pterostichus globosus (Coleoptera: Carabidae) on pupae of Bactrocera oleae (Diptera: Tephritidae). Bull. Entomol. Res. 106 (6), 701-709. http://dx.doi.org/10.1017/s0007485316000213.

Driscoll, D.A., Kirkpatrick, J.B., McQuillan, P.B., Bonham, K.J., 2010. Classic metapopulations are rare among common beetle species from a naturally fragmented landscape. J. Anim. Ecol. 79, 294-303. http://dx.doi.org/10.1111/j.1365-2656. 2009.01609.x.

Driscoll, D.A., 2008. The frequency of metapopulations, metacommunities and nestedness in a fragmented landscape. Oikos 117, 297-309. http://dx.doi.org/10.1111/j.2007. 0030-1299.16202.x.

Etienne, R.S., Olff, H., 2004. How dispersal limitation shapes Species-Body size. distributions in local communities. Am. Nat. 163, 69-83. http://dx.doi.org/10.1086/ 380582.

Eyre, M.D., McMillan, S.D., Critchley, C.N.R., 2016. Ground beetles (Coleoptera, Carabidae) as indicators of change and pattern in the agroecosystem: longer surveys improve understanding. Ecol. Ind. 68, 82-88. http://dx.doi.org/10.1016/j.ecolind. 2015.11.009.

Fernández-Escobar, R., de la Rosa, R., Leon, L., Gómez, J.A., Testi, L., Orgaz, F., Gil-Ribes, J.A., Quesada-Moraga, E., Trapero, A., Msallem, M., 2013. Evolution and sustainability of the olive production systems. In: Arcas, N., Arroyo López, F.N., Caballero, J., D’Andria, R., Fernández, M., Fernández-Escobar, R., Garrido, A., LópezMiranda, J., Msallem, M., Parras, M., Rallo, L., Zanoli, R. (Eds.), Options méditerranéennes - Series A: Mediterranean Seminars - Present and Future of the Mediterranean Olive Sector. CIHEAM, Zaragoza, pp. 11-41.

Flohre, A., Fischer, C., Aavik, T., Bengtsson, J., Berendse, F., Bommarco, R., Ceryngier, P., Clement, L.W., Dennis, C., Eggers, S., Emmerson, M., Geiger, F., Guerrero, I., Hawro, V., Inchausti, P., Liira, J., Morales, M.B., Oñate, J.J., Pärt, T., Weisser, W.W., Winqvist, C., Thies, C., Tscharntke, T., 2011. Agricultural intensification and biodiversity partitioning in European landscapes comparing plants, carabids, and birds. Ecol. Appl. 21, 1772-1781. http://dx.doi.org/10.1890/10-0645.1.

Fox, J., Weisberg, S., 2011. An $\{\mathrm{R}\}$ Companion to Applied Regression, second ed. Sage, Thousand Oaks, CA. http://socserv.socsci.mcmaster.ca/jfox/Books/Companion.

Fox, J., Weisberg, S., Hong, J., 2013. R Package 'effects': Effect Displays for Linear, Generalized Linear, Multinomial-logit, Proportional-odds Logit Models and Mixedeffects Models. (R package version 2. 3-0, available at: http://http:cran.r-project. orgwebpackageseffects).

Garnier, E., Cortez, J., Billes, G., Navas, M.L., Roumet, C., Debussche, M., Laurent, G., Blanchard, A., Aubry, D., Bellmann, A., Neill, C., Toussaint, J.P., 2004. Plant functional markers capture ecosystem properties during secondary succession. Ecology 85, 2630-2637. http://dx.doi.org/10.1890/03-0799.

Graham, M.H., 2003. Confronting multicollinearity in ecological multiple regression. Ecology 84, 2809-2815. http://dx.doi.org/10.1890/02-3114.

Guerrero, I., Carmona, G.P., Morales, M.B., Oñate, J.J., Peco, B., 2014. Non-linear responses of functional diversity and redundancy to agricultural intensification at the field scale in Mediterranean arable plant communities. Agric. Ecosyst. Environ. 195, 36-43. http://dx.doi.org/10.1016/j.agee.2014.05.021.

Hanson, H., Palmu, E., Birkhofer, K., Smith, H.G., Hedlund, K., 2016. Agricultural land use determines the trait composition of ground beetle communities. PLoS One 11, e0146329. http://dx.doi.org/10.1371/journal.pone.0146329.

Herzog, F., Steiner, B., Bailey, D., Baudry, J., Billeter, R., Bukácek, R., De Blust, G., De
Cock, R., Dirksen, J., Dormann, C.F., De Filippi, R., Frossard, E., Liira, J., Schmidt, T., Stöckli, R., Thenail, C., van Wingerden, W., Bugter, R., 2006. Assessing the intensity of temperate European agriculture at the landscape scale. Eur. J. Agron. 24, 165-181. http://dx.doi.org/10.1016/j.eja.2005.07.006.

Koivula, M., Punttila, P., Haila, Y., Nicnielii, J., 1999. Leaf litter and the small-scale distribution of carabid beetles (Coleoptera, Carabidae) in the boreal forest. Ecography 22, 424-435. http://dx.doi.org/10.1111/j.1600-0587.1999. tb00579.x.

Kotze, D.J., O'Hara, R.B., 2003. Species decline - but why? Explanations of carabid beetle (Coleoptera, Carabidae) declines in Europe. Oecologia 135, 138-148. http://dx.doi. org/10.1007/s00442-002-1174-3.

Kotze, D.J., Brandmayr, P., Casale, A., Dauffy-Richard, E., Dekoninck, W., Koivula, M.J., Lövei, G.L., Mossakowski, D., Noordijk, J., Paarmann, W., Pizzolotto, R., Saska, P., Schwerk, A., Serrano, J., Szyszko, J., Taboada, A., Turin, H., Venn, S., Vermeulen, R., Zetto, T., 2011. Forty years of carabid beetle research in Europe - from taxonomy, biology, ecology and population studies to bioindication, habitat assessment and conservation. ZooKeys 100, 55-148. http://dx.doi.org/10.3897/zookeys.100.1523.

Kromp, B., 1999. Carabid beetles in sustainable agriculture: a review on pest control efficacy, cultivation impacts and enhancement. Agric. Ecosyst. Environ. 74, 187-228.

Kuznetsova, A., Brockhoff, P.B., Christensen, R.H.B., 2014. R Package 'lmerTest': Tests in Linear Mixed Effects Models. (R package version 2. 0-20, available at: http://CRAN. R-project.org/package $=$ lmerTest).

Lövei, G.L., Magura, T., 2011. Can carabidologists spot a pitfall? The non-equivalence of two components of sampling effort in pitfall-trapped ground beetles (Carabidae). Comm. Ecol. 12, 18-22. http://dx.doi.org/10.1556/ComEc.12.2011.1.3.

Laliberté, E., Legendre, P., 2010. A distance-based framework for measuring functional diversity from multiple traits. Ecology 91, 299-305. http://dx.doi.org/10.1016/ S0167-8809(99)00037-7.

Lepš, J., Smilauer, P., 2003. Multivariate Analysis of Ecological Data Using CANOCO. Cambridge University Press, Cambridge.

MacLeod, A., Wratten, S.D., Sotherton, N.W., Thomas, M.B., 2004. 'Beetle banks' as refuges for beneficial arthropods in farmland: long-term changes in predator communities and habitat. Agr. Forest Entomol. 6, 147-154. http://dx.doi.org/10. 1111/j.1461-9563.2004.00215.x.

Maisonhaute, J.-E., Peres-Neto, P., Lucas, E., 2010. Influence of agronomic practices, local environment and landscape structure on predatory beetle assemblage. Agric. Ecosyst. Environ. 139, 500-507. http://dx.doi.org/10.1016/j.agee.2010.09.008.

Martins da Silva, P., Aguiar, C.A.S., Niemelä, J., Sousa, J.P., Serrano, A.R.M., 2008 Diversity patterns of ground-beetles (Coleoptera: Carabidae) along a gradient of landuse disturbance. Agric. Ecosyst. Environ. 124, 270-274. http://dx.doi.org/10.1016/j. agee.2007.10.007.

Martins da Silva, P., Aguiar, C.A.S., Silva, I.F., Serrano, A.R.M., 2011. Orchard and riparian habitats enhance ground dwelling beetle diversity in Mediterranean agroforestry systems. Biodivers. Conserv. 861-872. http://dx.doi.org/10.1007/s10531 010-9987-6.

McGarigal, K., Cushman, S.A., Neel, M.C., Ene, E., 2002. FRAGSTATS: spatial pattern analysis program for categorical maps. In: Computer Software Program Produced by the Authors at the University of Massachusetts. Amherst. . (Available from www. umass.edu/landeco/research/fragstats/fragstats.html).

Niemelä, J., Spence, J.R., 1994. Distribution of Forest Dwelling Carabids (Coleoptera): Spatial scale and the concept of communities. Ecography 17, 166-175. http://dx.doi org/10.1111/j.1600-0587.1994. tb00090.x.

Niemelä, J., Halme, E., Haila, Y., 1990. Balancing sampling effort in pitfall trapping of carabid beetles. Entomol. Fenn. 1, 232-238.

Niemelä, J., Haila, Y., Halme, E., Pajunen, T., Punttila, P., 1992. Heterogeneity in the spatial distribution of carabid beetles in the southern Finnish taiga. J. Biogeogr. 19, 173-181. http://dx.doi.org/10.2307/2845503.

Petit, S., Usher, M.B., 1998. Biodiversity in agricultural landscapes: the ground beetle communities of woody uncultivated habitats. Biodivers. Conserv. 7, 1549-1561. http://dx.doi.org/10.1023/A:1008875403868.

Ponce, C., Bravo, C., de León, D.G., Magaña, M., Alonso, J.C., 2011. Effects of organic farming on plant and arthropod communities: a case study in Mediterranean dryland cereal. Agric. Ecosyst. Environ. 141, 193-201. http://dx.doi.org/10.1016/j.agee. 2011.02.030.

Puech, C., Baudry, J., Joannon, A., Poggi, S., Aviron, S., 2014. Organic vs conventional farming dichotomy: does it make sense for natural enemies? Agric. Ecosyst. Environ. 194, 48-57. http://dx.doi.org/10.1016/j.agee.2014.05.002.

Purtauf, T., Dauber, J., Wolters, V., 2005. The response of carabids to landscape simplification differs between trophic groups. Oecologia 142, 458-464. http://dx. doi.org/10.1007/s00442-004-1740-y.

R Core Team, 2014. R: A Language and Environment for Statistical Computing. R Foundation for Statistical Computing, Vienna, Austria. http://www.R-project.org/.

Rao, C.R., 1982. Diversity and dissimilarity coefficients: a unified approach. Theor. Pop. Biol. 21, 24-43. http://dx.doi.org/10.1016/0040-5809(82)90004-1.

Rempel, R.S., Kaukinen, D., Carr, A.P., 2012. Patch Analyst and Patch Grid. Ontario Ministry of Natural Resources. Centre for Northern Forest Ecosystem Research, Thunder Bay, Ontario.

Ribera, I., Dolédec, S., Downie, I.S., Foster, G.N., 2001. Effect of land disturbance and stress on species traits of ground beetle assemblages. Ecology 82, 1112-1129. http:// dx.doi.org/10.1890/0012-9658(2001)082[1112:EOLDAS]2.0.CO;2.

Romero-Alcaraz, E., Ávila, J.M., 2000. Landscape heterogeneity in relation to variations in epigaeic beetle diversity of a Mediterranean ecosystem. Implications for conservation. Biodivers. Conserv. 9, 985-1005. http://dx.doi.org/10.1023/ A: 1008958720008 .

Rusch, A., Bommarco, R., Chiverton, P., Öberg, S., Wallin, H., Wiktelius, S., Ekbom, B., 2013. Response of ground beetle (Coleoptera, Carabidae) communities to changes in agricultural policies in Sweden over two decades. Agric. Ecosyst. Environ. 176, 
63-69. http://dx.doi.org/10.1016/j.agee.2013.05.014.

Santos, S.A.P., Cabanas, J.E., Pereira, J.A., 2007. Abundance and diversity of soil arthropods in olive grove ecosystem (Portugal): Effect of pitfall trap type. Eur. J. Soil Biol. 43, 77-83. http://dx.doi.org/10.1016/j.ejsobi.2006.10.001.

Sarthou, J.-P., Badoz, A., Vaissière, B., Chevallier, A., Rusch, A., 2014. Local more than landscape parameters structure natural enemy communities during their overwintering in semi-natural habitats. Agric. Ecosyst. Environ. 194, 17-28. http:// dx.doi.org/10.1016/j.agee.2014.04.018.

Schirmel, J., Mantilla-Contreras, J., Gauger, D., Blindow, I., 2015. Carabid beetles as indicators for shrub encroachment in dry grasslands. Ecol. Ind. 49, 76-82. http://dx. doi.org/10.1016/j.ecolind.2014.09.041.

Spake, R., Barsoum, N., Newton, A.C., Doncaster, C.P., 2016. Drivers of the composition and diversity of carabid functional traits in UK coniferous plantations. For. Ecol. Manage. 359, 300-308. http://dx.doi.org/10.1016/j.foreco.2015.10.008.

Stoate, C., Baldi, A., Beja, P., Boatman, N.D., Herzon, I., van Doorn, A., de Snoo, G.R., Rakosy, L., Ramwell, C., 2009. Ecological impacts of early 21 st century agricultural change in Europe - a review. J. Env. Manag. 91, 22-46. http://dx.doi.org/10.1016/ j.jenvman.2009.07.005.

Ulrich, W., Zalewski, M., 2007. Are ground beetles neutral? Basic Appl. Ecol. 8, 411-420. http://dx.doi.org/10.1016/j.baae.2006.08.002.

Vanbergen, A.J., Woodcock, B.A., Watt, A.D., Niemelä, J., 2005. Effect of land-use heterogeneity on carabid communities at the landscape scale. Ecography 28, 3-16. http://dx.doi.org/10.1111/j.0906-7590.2005.03991.x.

Vanbergen, A.J., Woodcock, B.A., Koivula, M., Niemelä, J., Kotze, D.J., Bolger, T. Golden, V., Dubs, F., Boulanger, G., Serrano, J., Lencina, J.L., Serrano, A., Aguiar, C.,
Grandchamp, A.-C., Stofer, S., Szél, G., Ivits, E., Adler, P., Markus, J., Watt, A.D., 2010. Trophic level modulates carabid beetle responses to habitat and landscape structure: a pan-European study. Ecol. Entomol. 35, 226-235. http://dx.doi.org/10. 1111/j.1365-2311.2010.01175.x.

Vandewalle, M., de Bello, F., Berg, M.P., Bolger, T., Dolédec, S., Dubs, F., Feld, C.K., Harrington, R., Harrison, P.A., Lavorel, S., Martins da Silva, P., Moretti, M., Niemelä, J., Santos, P., Sattler, T., Sousa, J.P., Sykes, M.T., Vanbergen, A.J., Woodcock, B.A., 2010. Functional traits as indicators of biodiversity response to land use changes across ecosystems and organisms. Biodivers. Conserv. 19, 2921-2947. http://dx.doi. org/10.1007/s10531-010-9798-9.

Werling, B.P., Gratton, C., 2008. Influence of field margins and landscape context on ground beetle diversity in Wisconsin (USA) potato fields. Agric. Ecosyst. Environ. 128, 104-108. http://dx.doi.org/10.1016/j.agee.2008.05.007.

Woltz, J.M., Isaacs, R., Landis, D.A., 2012. Landscape structure and habitat management differentially influence insect natural enemies in an agricultural landscape. Agric. Ecosyst. Environ. 152, 40-49. http://dx.doi.org/10.1016/j.agee.2012.02.008.

Woodcock, B.A., Westbury, D.B., Potts, S.G., Harris, S.J., Brown, V.K., 2005. Establishing field margins to promote beetle conservation in arable farms. Agric. Ecosyst. Environ. 107, 255-266. http://dx.doi.org/10.1016/j.agee.2004.10.029.

Woodcock, B.A., Redhead, J., Vanbergen, A.J., Hulmes, L., Hulmes, S., Peyton, J., Nowakowski, M., Pywell, R.F., Heard, M.S., 2010. Impact of habitat type and landscape structure on biomass, species richness and functional diversity of ground beetles. Agric. Ecosyst. Environ. 139, 181-186. http://dx.doi.org/10.1016/j.agee. 2010.07.018. 